\title{
The Influence Of Smoking On Hemoglobin Rate In Blood At Active Smoker
}

Zulliati* $^{1}$, Academi Of Midwifery Sari Mulia Banjarmasin Indonesia ${ }^{1}$ zulliati@akbidsarimulia.ac.id

Dede Mahdiyah $^{1}$ Academi Of Midwifery Sari Mulia Banjarmasin Indonesia ${ }^{1}$ dede_mahdiyah@akbidsarimulia.ac.id

\begin{abstract}
Objective: To analyze the effect of smoking on Hemoglobin $(\mathrm{Hb})$ level in the blood of active smokers at Health care center of East Banjarmasin.

Technology or Method: This study used Cross-Sectional, with sample 60 people in Health care center area of eastern city of East Banjarmasin . Data analyzed using Chi Square test with a confidence level of $95 \%$.

Results: This study showed that there was a significant difference of hemoglobin level in active smokers with $(p=0.001<\alpha 0.005)$.

Conclusion: Smoking will have a significant effect on the decrease of blood hemoglobin levels On active smokers.
\end{abstract}

Keywords: Active smoker, Effect of smoking, Hemoglobin, Smoking.

\section{INTRODUCTION}

The smoking habits are widespread almost in all groups of people in the world including Indonesia. Word Health Organization (WHO) reported that Indonesia was ranked third with the largest number of smokers in the world after China and India. [1] There are four factors that influence the degree of health in adolescence and adulthood are behavioral factors, environment, heredity and health services.
One of the four factors is often done behavior, namely smoking behavior [2]

Active smokers will release cigarette smoke containing $\mathrm{CO}$ (carbon monoxide) gas at concentrations over 20,000 ppm (parts per million) which then dilute around 4005000 ppm (parts per million) during sucking. High concentrations of $\mathrm{CO}$ (carbon monoxide) gas in cigarette smoke cause $\mathrm{COHb}$ (karboksihemoglobin) in the blood of smoking to increase. This situation is absolutely very dangerous to the health of 
the smoker itself. The content in cigarettes has a concentration of $\mathrm{CO}$ (carbon monoxide) of $0.1 \%$ - $10 \%$. Smoking generally has $8 \%-10 \%$ levels of $\mathrm{CO}$ (carbon monoxide) in the blood circulation is what causes heavy smokers are susceptible to heart attacks. [3]

Absorption and metabolism of carbon monoxide in the tissues: carbon monoxide is absorbed through the lungs and diffuses through the alveolar capillary membrane. Carbon monoxide exchange between inhaled air and blood is controlled by mass (physical, transport and diffusion) and physiological mechanisms (alveolar ventilation and output cardiac output). [4] After being absorbed, $\mathrm{CO}$ (carbon monoxide) diffuses through the plasma, passes through the red blood cell membrane, and eventually enters the red blood cell stroma where CO (carbon monoxide) binds to hemoglobin and forms carboxyhemoglobin $(\mathrm{COHb})$ bonds. Reduces blood capacity in carrying oxygen and interferes with the release of oxygen to the tissues. As a result will disrupt the delivery of oxygen, cellular respiration and cause tissue hypoxia [5]

Health research data base ( Riskesdas ) 2010 mention that, south Kalimantan including the regions with the smokers high enough. Which reached 30,5 percent as active smokers. With the majority of smokers still young age. According to data in South Kalimantan, Banjarmasin particularly regional data from the city health department said that in 2013, 1338 show about teenager smoking, of them for adolescent girls 3 students and to boy teenagers as 1335. [6]

According to the preliminary study conducted at some health centers municipalities Banjarmasin east of 10 the active smokers, the levels found hemoglobin is 4 active smokers of them is about low hemoglobin and 6 of them is hemoglobin normal.

This study attempts to analyze effect on the smoking hemoglobin ( $h b$ ) in the blood on active smokers.

\section{METHODS}

In this study methods used correlation study design used the research cross sectional the research going to get the effects of one state to the another in a the same time to approach, observation, data collection and aims to analyze smoking in the effects of hemoglobin in blood on active smokers research [7]. Population is the whole the subject or object with particular characteristics to be examined. [8] The 
population in research is active smokers in 2 health care center on working areas Banjarmasin east. Data collection using statistic and analysis using Chi Square with significance value $\alpha=0,05$.

\section{RESULTS}

The results of research conducted with univariate and bivariate analysis.

\section{Analysis univariat}

The analysis univariat it consists of the percentage the results of investigation hemoglobin through blood sample taking with a hemoglobin digital in two health care center the working areas of banjarmasin east 53 respondents were we can see in table as follows:

Table 1. Results of Hemoglobin Examination in active smokers.

\begin{tabular}{|c|c|c|c|c|}
\hline $\begin{array}{c}\text { No } \\
\text {. }\end{array}$ & $\begin{array}{c}\begin{array}{c}\text { Levels of } \\
\text { hemoglobin } \\
\text { (Hb) }\end{array}\end{array}$ & $\begin{array}{c}\text { Total } \\
\text { respondent } \\
\text { S }\end{array}$ & $\begin{array}{c}\text { percentage } \\
(\%)\end{array}$ & $\begin{array}{l}\text { Caption } \\
\text { hemogl } \\
\text { obin }\end{array}$ \\
\hline 1. & $12 \mathrm{gr} / \mathrm{dl}$ & 22 & $41 \%$ & Rendah \\
\hline 2. & $13 \mathrm{gr} / \mathrm{dl}$ & 16 & $30 \%$ & Rendah \\
\hline 3. & $14 \mathrm{gr} / \mathrm{dl}$ & 13 & $25 \%$ & Normal \\
\hline \multirow[t]{2}{*}{4.} & $15 \mathrm{gr} / \mathrm{dl}$ & 2 & $4 \%$ & Normal \\
\hline & Total & 53 & $100 \%$ & \\
\hline
\end{tabular}

Table 1. shows that of the 53 respondents studied, the number of respondents who have hemoglobin $(\mathrm{Hb})$ level $12 \mathrm{gr} / \mathrm{dl}$ of 22 respondents $(41 \%)$, which has hemoglobin $(\mathrm{Hb})$ $13 \mathrm{gr} / \mathrm{dl}$ level of 16 respondents (30\%), which has hemoglobin $(\mathrm{Hb})$ level $14 \mathrm{gr} / \mathrm{dl}$ as many as 13 respondents $(25 \%)$ and who have hemoglobin (Hb) $15 \mathrm{gr} / \mathrm{dl}$ as much as 2 respondents (4\%). So the results of hemoglobin examination, obtained two categories of hemoglobin $(\mathrm{Hb})$ low level and normal hemoglobin ( $\mathrm{Hb})$ levels and most of the results of hemoglobin $(\mathrm{Hb})$ examination has a low hemoglobin level of 38 respondents $(71 \%)$.

After data collection in research Classification smokers active than two health care center the working areas of banjarmasin east can be seen in table as follows.

Table 2 the results of Classification in smokers active in two health care center the working areas of banjarmasin east:

\begin{tabular}{cccc}
\hline No. & $\begin{array}{c}\text { Classification } \\
\text { smoker }\end{array}$ & $\begin{array}{c}\text { Total } \\
\text { respondents }\end{array}$ & Presentage \\
\hline 1. & Light smokers & 4 & $7 \%$ \\
2. & Medium & 21 & $39,6 \%$ \\
& Smokerpp & & \\
3. & Heavy Smokers & 28 & $54,8 \%$ \\
& Total & 53 & $100 \%$ \\
\hline
\end{tabular}

Table 2 shows that out of the 53 respondents are examined, the number of respondents with heavy smokers as much as 28 respondents $(54.8 \%)$, moderate smokers by as much as 21 respondents (39\%), light smokers as much as 4 respondents (7\%). So the majority of the respondents the majority of heavy smokers that is as much as 28 respondents with percentage of $54.8 \%$. 


\section{Analysis bivariat}

analysis bivariat is analysis to seen any effect smoking hemoglobin in smokers active in health care center the working areas of banjarmasin the east as follows

Table 3 relations smoking hemoglobin $(\mathrm{Hb})$ in smokers active in health care center the working areas of banjarmasin east.

\begin{tabular}{|c|c|c|c|c|c|c|}
\hline \multirow{3}{*}{ smoker } & \multicolumn{4}{|c|}{ Hemoglobin } & \multirow{2}{*}{\multicolumn{2}{|c|}{ Total }} \\
\hline & \multicolumn{2}{|c|}{$\begin{array}{c}\text { Low } \\
\text { hemoglobin }\end{array}$} & \multicolumn{2}{|c|}{$\begin{array}{c}\text { Normal } \\
\text { Hemoglobin }\end{array}$} & & \\
\hline & $\mathrm{n}^{*}$ & $\%$ & $\mathrm{n}^{*}$ & $\%$ & $\mathrm{n}^{*}$ & $\%$ \\
\hline $\begin{array}{c}\text { Not } \\
\text { smokers }\end{array}$ & 22 & $100 \%$ & 0 & $0 \%$ & 22 & $\begin{array}{c}100 \\
\%\end{array}$ \\
\hline $\begin{array}{c}\text { Light } \\
\text { smokers }\end{array}$ & 11 & $64,7 \%$ & 6 & $35,3 \%$ & 17 & $\begin{array}{c}100 \\
\%\end{array}$ \\
\hline $\begin{array}{c}\text { Medium } \\
\text { Smokerpp }\end{array}$ & 3 & $30,0 \%$ & 7 & $70,0 \%$ & 10 & $\begin{array}{c}100 \\
\%\end{array}$ \\
\hline $\begin{array}{c}\text { Heavy } \\
\text { Smokers }\end{array}$ & 2 & $50,0 \%$ & 2 & $50,0 \%$ & 4 & $\begin{array}{c}100 \\
\%\end{array}$ \\
\hline Total & 38 & $71,7 \%$ & 15 & $28,3 \%$ & 53 & $\begin{array}{c}100 \\
\%\end{array}$ \\
\hline Chi Squa & & & & 0,05 & & \\
\hline
\end{tabular}

Based on the results of table 3 shows that of 53 the treatment respondents, respondents were not smokers in the hemoglobin low as many as $22(100 \%)$ of respondents and in the hemoglobin normal as many as 0 respondents.Smokers light in the hemoglobin low as many as $11(64,7 \%)$ of respondents and in the hemoglobin normal as many as $6 \quad(35.3 \%)$ of respondents.Smokers and in the hemoglobin low about three $(30,0 \%)$ of respondents and in the hemoglobin normal as many as 7 $(70,0 \%)$.A heavy smoker in the hemoglobin low as much as two (50\%) of respondents and hemoglobin normal as much as two (50) of respondents.And in get me the results on $\mathrm{p}$ value $>0.05$ so Ho rejected. From our analysis could be met conclusion that is Ho rejected, or is the between harm of smoking by elevated levels of hemoglobin ( $\mathrm{Hb}$ ) in smokers active in health care center the working areas of banjarmasin east.

\section{DISCUSSION}

Cigarettes are processed tobacco using materials or without ingredients, in addition cigarettes are also an addictive substance that is harmful to the human body and is one cause of respiratory diseases. Cigarettes can also increase the production of blood hemoglobin [9]

Examination results are in line with research conducted by danusantosa (2013) is the studed epidemiology conducted showed sump smoking is a risk factor for the syndrome myelodisplastic and refractory anemia. This study showed an increased risk relative to the refractory anemia (odds ratio, OR 2.5; $95 \%$ confidence interval, $\mathrm{CI}=1.2-$ 5.6). This one can say that smoke can lead to decreased levels of hemoglobin in the blood. [10]

In a previous study states there are different levels of hemoglobin corroborating 
this study, where the results showed that there are statistically significant differences in blood hemoglobin levels in male smokers and nonsmokers in seventh semester student of Faculty of Medicine, University of Sam Ratulangi Manado, in this study blood hemoglobin levels were found in smokers higher than nonsmokers. Thus this study and previously had a relationship stronger

This study is also supported by a journal conducted by Timothy et all showed average hemoglobin levels and serum Cintini in heavy smokers have elevated hemoglobin levels where the addictive substances present in cigarettes are carcinogenic, Ethylene oxide (EO) found in cigarettes are also carcinogenic, which indirectly affects the circulation of the blood vessels so that patients classified as heavy smokers of 1 to 2 packs a day had a risk of myeolodiplastik syndrome. [12]

\section{CONCLUSION}

Cigarettes are tobacco containing addictive substances, which are harmful to the human body and can lead to bloodrelated diseases. The addictive substance in cigarettes affect hemoglobin levels in active smokers. In this study show that smoking can lead to increased and decreased levels of hemoglobin in the blood. So that active smokers will be very susceptible to myeolodiplastic syndrome and refractory anemia.

\section{REFERENCES}

[1] Kipyatulizam, Akbar M R, Triyani Y. pengaruh kebiasaan merokok terhadap kadar hemoglobin dan tingkat kebugaran jasmani. Prosiding PendDok. Bandung 2014.

[2] Araujo, D. Hubungan Tingkat Pengetahuan tentang Merokok dengan Perilaku Merokok. Yogyakarta. 2009.

[3] Aritonang, M R.Fenomena Wanita Merokok. Jurnal Psikologi UGM, Yogyakarta :Universitas GadjahMada Press.

[4] Fierro M. Adverse Health Effects Of Exposure To Ambient Carbon Monoxide. The University of Arizona, College of Public Health. 2013. Page 134-146

[5] Kementerian Kesehatan RI. Profil Kesehatan Indonesia 2014. Jakarta: Kementerian Kesehatan RI; 2015.

[6] Diagnostic and Statistical Manual of Mental Disorders, Fourt Edition (DSM-IV). Washington DC. American Psychiatric Asociation, 1994

[7] Bustan, M. N. Epidemiologi Penyakit Tidak Menular. Jakarta : Rineka Cipta.2010

[8] Hidayat, A. Metode Penelitian Kebidanan dan Teknik Analisis Data. Jakarta : Salemba Medika. 2011.

[9] Hastono, S.P. Analisis Data Kesehatan. Jakarta : FKM UI. 2007 
[10] Danusantoso H. Peran radikal bebas terhadap beberapa penyakit paru. JKedokteran Trisakti, 2013:22(1):316.

[11] Iqbal, Hasan. Anilisis Data Penelitian Dengan Statistik. Jakarta : PT Bumi Aksara. 2006

[12] Makawekes MT, Kalangi SJR, Pasiak TF. Perbandingan kadar hemoglobin darah pada pria perokok dan bukan perokok. E-Biomedik (ebm) Jan-Jun 2016:Vol.4 (1).

[13] Tomothy R, Fennel, John P.M, Richard W, Morris, Mary W, et all. Hemoglobin Adducts From Acrylonitrile and Ethylene Oxide in Cigarette Smokers: Effects of Glutathione S-Transferase T1-Null and M1-Null Genotypes. Cancer Epidemiology, Biomarkers \& Prevention. July 2000: Vol 9 :page 705-712. 